\title{
Effects of using chemical admixture with nanosilica in the consistency and mechanical strength of concrete
}

\author{
Efeitos do uso de aditivo com nanosílica na \\ consistência e resistência mecânica do concreto
}
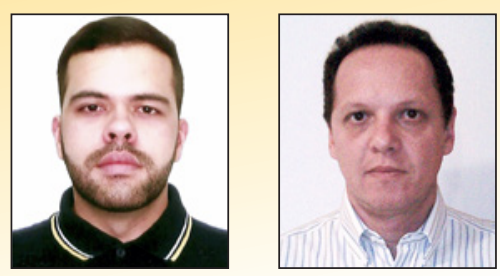

\author{
T. F. CAMPOS NETO \\ tiagocampos.eng@gmail.com \\ https://orcid.org/0000-0002-9618-2763 \\ A. L. B. GEYER \\ andre.geyer@hotmail.com \\ https://orcid.org/0000-0003-2799-4474
}

\begin{abstract}
The concrete's performance depends on its behavior in the fresh and hardened states, since the workability corroborates for the transport and application processes of the material, while the mechanical strength guarantees structural effectiveness and functionality. Generally, studies of nanosilica (nS) are focused on performance analysis in the hardened state and they are founded on the use of the mineral admixture in dry grains. Thus, this article aims to evaluate the effects of superplasticizer admixture use with nanosilica in colloidal suspension in the consistency and mechanical strength of the concrete. Two concrete mixtures were produced with the same materials and identical proportions, however with different superplasticizes, one with nanosilica (CnS) and the other without nanosilica (CC) used as reference to analyse the effects of the presence of mineral admixture in the development of the consistency and the mechanical strength of the concrete. For evaluation of these properties were carried slump tests as a function of time and compressive strength at 28 days, according to ABNT NBR 10342 and NBR 5739, respectively. The results showed that the concrete without nanosilica presented longer time available for handling, achieving 135 minutes, extending its period of slump loss for fifteen minutes besides the concrete with nanosilica, which reached 120 minutes; and, also presented higher slump values throughout the test, reaching up to $60.0 \mathrm{~mm}$ above at 75 minutes after the beginning of test. However, the $\mathrm{CnS}$ presented better performance in the hardened state, achieving the $\mathrm{C} 70$ high performance concrete class with $70.92 \mathrm{MPa}$; while the $\mathrm{CC}$ reached $65.57 \mathrm{Mpa}$, fitting within the C60 class.
\end{abstract}

Keywords: concrete, superplasticizer admixture, nanosilica, workability, mechanical strength.

\section{Resumo}

O desempenho do concreto depende do seu comportamento nos estados fresco e endurecido, haja vista que a trabalhabilidade corrobora para os processos de transporte e aplicação do material, enquanto a resistência mecânica garante eficácia e funcionalidade estrutural. Geralmente, estudos de misturas com nanosílica (nS) são voltados para análise do desempenho no estado endurecido e são fundados no uso da adição mineral em grãos secos. Dessa forma, este artigo tem o objetivo de avaliar os efeitos do uso de aditivo superplastificante com nanosílica em suspensão coloidal na consistência e resistência mecânica do concreto. Foram produzidos dois concretos com mesmos materiais e traços idênticos, no entanto com aditivos superplastificantes diferentes, sendo uma mistura incorporada com aditivo com nanosílica (CnS) e outra sem a adição mineral (CC) utilizada como referência para análise dos efeitos da presença da nanosílica, tanto na evolução da consistência como na resistência mecânica do concreto. Para avaliação dessas propriedades foram realizados ensaios de perda de abatimento em função do tempo e resistência à compressão aos 28 dias conforme ANBT NBR 10342 e NBR 5739, respectivamente. Os resultados mostraram que o concreto dosado com aditivo sem nanosílica apresentou maior tempo disponível para manuseio, alcançando 135 minutos, estendendo o período de perda de abatimento por quinze minutos além do concreto com nanosílica em suspensão coloidal, que atingiu 120 minutos; bem como apresentou maiores valores de abatimento durante todo o ensaio, chegando a atingir $60,0 \mathrm{~mm}$ a mais de abatimento aos 75 minutos após o início do ensaio. Entretanto, o CnS apresentou melhor desempenho no estado endurecido, batendo a classe C70 de concreto de alto desempenho com 70,92 MPa; enquanto o CC alcançou 65,57 MPa, se enquadrando na classe C60.

Palavras-chave: concreto, aditivo superplastificante, nanosílica, trabalhabilidade, resistência mecânica. 


\section{Introduction}

Fresh concrete hardens over time, especially if mixed continuously, the result of prolonged mixing is associated with accelerated loss of slump of the mixture. The loss of workability can create a series of problems including casting difficulty, resulting in a more porous concrete with low mechanical strength and durability [1].

The properties related to workability include consistency, segregation, exudation, plasticity and finishing. The consistency is considered an indicator closer to workability, i.e. it is a parameter that easily measures the flowability and cohesion of the concrete. The slump test is used as a measure of the concrete's consistency [2] Nanotechnology was defined by Drexler et al. (1991 apud SAID et al. [3]) as "the control of the matter's structure based on the control of molecule per molecule of the products and byproducts". Nanotechnology can be considered as one of the most modern topics in the areas of science and technology. Due its great market potential and economic impact, the need for exploration in this field and its applications has grown significantly in recent decades.

Nowadays there are a large number of applications of nanotechnology in the civil engineering area. The study of nanomaterials is a growing field the has attracted interest e has been applied in issues ranging from the manufacture of new products to the search for new applications. Thus, it is fundamental that their physical and chemical properties must be studied as well as their behavior in the mixtures with another material.

One of the most used products is the nanosilica (nS) and, although it is widely used for improving the properties of mixtures, e.g. decreasing the porosity of the cementitious material, its applications and effects on concretes have not been fully known yet. According to Nili, Ehsani and Shabani (2010 apud QUERCIA et al. [4]), nanosilica is capable of increasing compressive strength and reducing the total permeability of hardened concrete.

It is known that the performance of the concrete depends on its behavior both in the hardened and fresh states, since the mechanical strength guarantees structural effectiveness and functionality, while the workability corroborates with the transport and application processes. Most studies of concrete with nanosilica are focused on the analysis of its impacts on the hardened mixture and little is known about the impacts on the fresh mixture. In addition, the studies are mostly performed with nanosilica dry grains condition. Thus, this paper aims to evaluate the effects of using superplasticizer admixture with nanosilica in colloidal suspension on the consistency and mechanical strength of the concrete.

\section{Concrete and nanosilica}

Concrete is a material used in building structures and substructures. It consists of different sizes granular materials and the granulometry of these products in the mixture, which contains particles from $300 \mathrm{~nm}$ to $32 \mathrm{~mm}$, determines the properties of the concrete. Fresh properties, e.g. are regulated by the distribution of these different sizes particles, as well as properties in the hardened state, such as mechanical strength and durability, which can also be affected by the resulting densification of the particles. Increasing the range of grains sizes is one way to improve the distribution of the particles, e.g. including particles smaller than $30 \mathrm{~nm}$ Some materials have been widely used such as silica fume and nanosilica [5]. The development of new technologies for concrete results from the emergence of new cementitious materials science, new chemical and mineral admixtures science and the use modern scientific equipment to characterize the microstructure and nanostructure. For Zhu, Bartos and Porro (2004 apud GLEIZE [6]) the addition of nanomaterials in concrete mixtures allows not only a better control of their microstructure, which some current technologies do not, but also the production of more durable and resistant materials. According to Kim et al. [7], the main cement hydration product is the hydrated calcium silicate (C-S-H) which consists of $67 \%$ of the total hydrated products. This product can be altered by the incorporation of nanoparticles. It is known that the transition zone (aggregate-cement paste interface) is the most fragile region of concrete, however it can be reduced by the addition of pozzolanic materials. Pozzolans are able to consume some hydration products, e.g. calcium hydroxide $(\mathrm{CH})$ in the pozzolanic reactions resulting in a increase of the $\mathrm{C}-\mathrm{S}-\mathrm{H}$ amounts and reducing the transition zone thickness.

Said et al. [3] affirm that $\mathrm{nS}$ can be presented in two different types: compacted dry grains or colloidal suspension. The nS dry grains must undergo a special preparation procedure before being addicted into concrete, thus ensuring complete dispersion in the mixture. On the other hand colloidal suspension nS, produced as a stabilized suspension by a dispersing agent, is a ready-to-use type. Campillo, Dolado and Porro (2003 apud SAID et al. [3]) studied the properties of mortars produced with the two different types and concluded that the behavior of the mixtures incorporated with colloidal suspension nS was better. The researchers attributed the results to the better dispersion of nS with high reduction of agglomeration compared to the mixtures with dry grains of nanosilica. Different effects are caused by addicting nanosilica or silica fume in concretes. The addition of silica fume decreases the required amount of cement, which is a more pronounced effect for nS. The main mechanism of this work principle is the high specific surface which acts as nucleation points for precipitation of the C-S-H [5]. For Bjornstrom et al. (2004 apud BASTAMI; BAGHBADRANI; ASLANI [8]) it is still unclear whether the acceleration in the hydration process of the cement incorporated with nS is caused by its pozzolanic reactivity by dissolution or by its high specific surface. Viscosity test results have shown that cement pastes or mortars incorporated with $\mathrm{nS}$ require more water to maintain workability. In addition, the nanosilica presents a strong tendency to suffer ionic adsorption in aqueous environment, so the formation of agglomerates is expected. In the latter case, plasticizing admixtures are indicated.

In general, silica fume competes to retard the exothermic cement reaction and also reduces the concrete permeability. Concretes with silica fume have a delayed hydration process because hydration particles are separated by the presence of silica and as a consequence, the hydration heat is lower, being proportional to the clínquer content. Nevertheless, Belkowitz and Armentrout (2009 apud SAID et al. [3]) investigated the effects of $\mathrm{nS}$ in the cement hydration process and found that the small size of $n S$ particles provides a larger contact surface, which accelerates the cement hydration rate and pozzolanic reactions.

El-Baky, Yehia and Khalil [9] evaluated the performance of fresh cement Portland mortars incorporated with dry grains of nanosilica. 


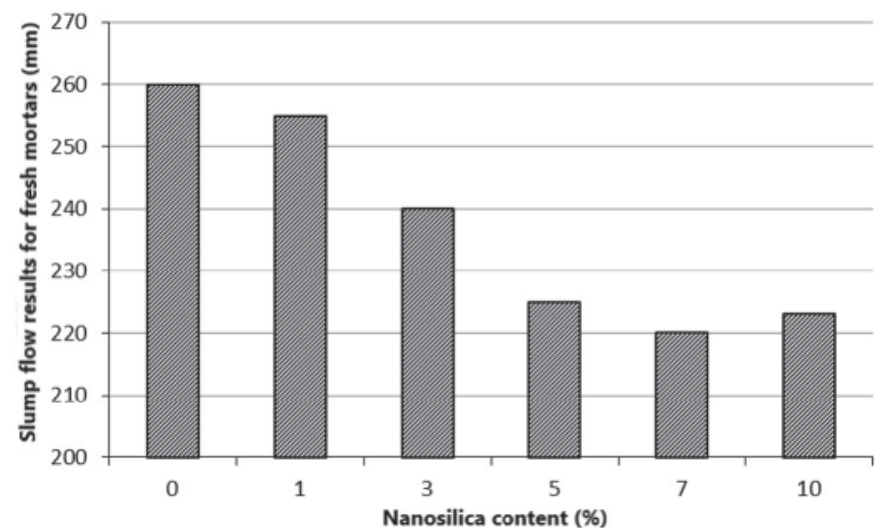

Figure 1

Mortars flowability with different contents of $\mathrm{nS}$

Source: Adapted from EL-BAKY; YEHIA; KHALIL [9]

The cement was substituted for $19 \mathrm{~nm}$ dry grains of $\mathrm{nS}$ in contents of $0,1,3,5,7$ and $10 \%$; the water/agglomerates ratio (w/ag) was kept constant and equal to 0.48 ; and the fine aggregate proportion was 2.75 as function of the cement amount. The mortars ' flowability tests were performed according to ASTM C1437 (Standart Test Method for Flow of Hydraulic Cement Mortar) and the results showed that the reduction of flowability is proportional to the increase of nS percentage in the mixtures up to $7 \%$, since that part of the water was used in the activation of high specific surface nanosilica (Figure 1). Though, this behavior is different when the nS percentage reaches $10 \%$, where the flowability increases again due the excess of nanoparticles. Thus, at lower concentrations, nS absorbs some of the water content reducing the flowability of mortars, while at higher concentrations, nS works as a lubricant increasing the flowability of the mixture.

Still in the same study, the researchers performed micrographs using scanning electron microscopy (SEM) on hydraulic cement mortars without nanosilica (conventional) and with $7 \%$ of $n S$ in fuction of cement content. The results indicated that the nS incorporated mortar is denser and more homogeneous than the conventional one. The authors attributed the results to the pozzolanic reactions which corroborated to a greater cohesion presenting lower workability. When it comes to mechanical performance, Said et al. [3] studied concrete mixtures produced with different colloidal suspension nanosilica

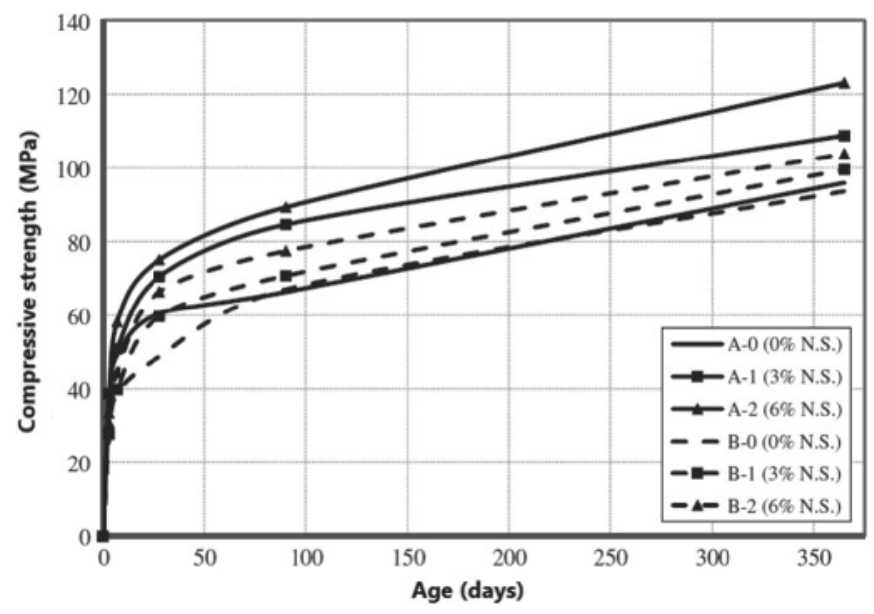

Figure 2

Compressive strength evolution of the mixtures Source: Adapted from SAID et al. [3]

contents (0, 3 and $6 \%$ ). Three concrete mixtures were incorporated with $\mathrm{nS}$ and other three mixtures were incorporated with $\mathrm{nS}$ and fly ash (class F) as specified by ASTM C618 (Standart Specification for Coal Fly Ash or Calcined Natural Pozzolan for Use in Concrete). Cementitious material consumption was maintained constant $(390 \mathrm{~kg} /$ $\mathrm{m}^{3}$ ) as well as the water/cementitious materials ratio $(0.40)$. Mechanical strength, permeability and porosity of concrete were evaluated. The results showed that the samples with $6 \%$ of $n S$ achieved higher mechanical strengths and when nS is used together with fly ash the development of the mechanical strength in long term can be affected. Figure 2 presents the development of compressive strengths of the analyzed mixtures where Group A consists of concretes with $\mathrm{nS}$ and Group B consists of concretes with nS and fly ash.

The permeability was analyzed by the chloride ion penetration test which defines the chloride penetration depth by the colorimeter method according to ASTM C1202 (Standart Test Method for Electrical Indication of Concrete's Ability to Resist Chloride Ion Penetration). On the other hand, the porosity was evaluated through the mercury injection porosimetry test which determines the total porosity of the concrete and the pore threshold diameters. The test's results are set in Table 1.

\section{Table 1}

Permeability and porosity results of the concretes

\begin{tabular}{|c|c|c|c|c|}
\hline \multirow[b]{2}{*}{ Mixture } & \multicolumn{2}{|c|}{ Permeability } & \multicolumn{2}{|c|}{ Porosity } \\
\hline & $\begin{array}{l}\text { Penetration depth } \\
(\mathrm{mm})\end{array}$ & $\begin{array}{l}\text { Penetration class } \\
\text { (ASTM C 1202) }\end{array}$ & $\begin{array}{c}\text { Total apparent } \\
\text { porosity } \\
(\%)\end{array}$ & $\begin{array}{l}\text { Pores diameters } \\
\qquad(\mu \mathrm{m})\end{array}$ \\
\hline $\mathrm{A}-\mathrm{O}(\mathrm{O} \% \mathrm{nS})$ & 10.2 & Low & 10.13 & 0.100 \\
\hline A-1 $(3 \% n S)$ & 3.1 & Very low & 6.91 & 0.075 \\
\hline A-2 $(6 \% n S)$ & 4.6 & Very low & 6.44 & 0.060 \\
\hline B-0 (0\% nS) & 8.1 & Very low & 12.56 & 0.144 \\
\hline B-1 (3\% nS) & 4.1 & Very low & 9.30 & 0.092 \\
\hline B-2 (6\% nS) & 3.3 & Very low & 8.21 & 0.075 \\
\hline
\end{tabular}


Group A concretes presented lower chloride ion penetration indices reaching to $70 \%$ lower rates when compared to concretes without nS. Group B concretes presented a slight reduction and close to $60 \%$ of the concrete without nS. When it comes to porosity, all the concretes incorporated with nanosilica showed lower porosities and smaller pore threshold diameters. These results confirm that nanosilica works not only as a pozzolanic material but also as a filler.

Kim et al. [7] analyzed the effects of nanosilica in the composition of concretes under different curing temperatures. Three mixtures with different nS contents $(0,1$ and $3 \%)$ and temperatures conditions on seven days curing processes $\left(20\right.$ and $\left.38^{\circ} \mathrm{C}\right)$ were studied. The main subject was to evaluate the cement hydration rate and the relative pozzolanic reactivity of nanosilica. The results evidenced an accelerated cement hydration process under higher temperatures and that the nS portion that actively participated in the pozzolanic reactions was higher when the cement paste is submitted to elevated temperatures.

The selection of appropriate materials and preparing processes are important steps to produce a concrete mixture that ensures the strength and durability specifications of the structure project. Thought, this objective cannot be achieved if right attention is not given to the operations which the mixtures is submitted in the early ages. The term "early ages" covers only an insignificant time period, e.g. the first two days after its production, but during this period numerous operations are performed such as mixing, casting, finishing, curing and demolding. These operations are influenced by fresh concrete characteristics, e.g. workability, strength growth rate and maturity time. Obviously, simultaneous control of these operations in early ages and these fresh concrete properties is essential to ensure that the final product is structurally suitable for its purpose, for its design [10].

The early ages period in concrete service life is insignificantly smaller than its total service life, but during this period it is subject to many operations that are not only affected by the concrete properties but also influence them, e.g. a concrete with low workability can be difficultly mixed; on the other hand, excessive mixing time can reduce its workability.

For a constant water/cement (w/c) ratio an increase in aggregate/ cement $(\mathrm{ag} / \mathrm{c})$ ratio will reduce its workability and consequently a larger cement amount will be required. A lower fine aggregate content results in higher rates of segregation and rough finishing while a higher fine aggregate content could result in a more permeable and less economical and durable but more easily workable mixture [11]. Smaller particles require more water because of their large specific surfaces, while the irregular shapes and rough textures of an angular aggregate could require more water that a rounded aggregate. The mineral materials incorporated with the purpose of replacing part of the cement also impact on the workability increasing the cohesion of the mixture.

Mixing time and speed can damage the concrete's workability. The Designation C94 [12] states that mixing in elevated speeds and for long periods of time, approximately one hour or more, may result in a mechanical strength loss, excessive loss of incorporated air and accelerated slump loss.

The superplasticizer admixtures are responsible for ensuring high flowability to the mixtures, however Tutikian and Dal Molin [13] affirm that the greatest difficulty in using this type of admixtures is the relatively high rate of consistency loss with the time. Thought, in cases where a longer transport and casting time is necessary it is indicated the specification of higher initial slumps which can be obtained with the use of plasticizing admixtures.

\section{Materials and experimental program}

\subsection{Materials}

For the development of the experimental procedure the following materials were used: cement Portland CP II-F-40 with specific surface of $422.31 \mathrm{~m}^{2} / \mathrm{kg}$; silica fume; fine aggregates with characteristic maximum diameters of 0.60 and $4.75 \mathrm{~mm}$; coarse aggregates with 12.5 and 25.0 mm; multi-functional admixture (Tec-Mult 829);

\section{Table 2}

Aggregates characteristics and chemical admixtures specifications

\begin{tabular}{ccccc}
\hline Characteristic & \multicolumn{3}{c}{ Aggregates } \\
\cline { 2 - 5 } & $\begin{array}{c}\text { Fine aggregate } \\
\mathbf{0 . 6} \mathbf{~ m m}\end{array}$ & $\begin{array}{c}\text { Fine aggregate } \\
\mathbf{4 . 7 5} \mathbf{~ m m ~}\end{array}$ & $\begin{array}{c}\text { Coarse aggregate } \\
\mathbf{1 2 , 5} \mathbf{~ m m}\end{array}$ & $\begin{array}{c}\text { Coarse aggregate } \\
\mathbf{2 5 , 0} \mathbf{~ m m}\end{array}$ \\
\hline $\begin{array}{c}\text { Unit weight } \\
\left(\mathrm{kg} / \mathrm{dm}^{3}\right)\end{array}$ & 1.366 & 1.537 & 1.620 & 1.671 \\
$\begin{array}{c}\text { Specific weight } \\
\left(\mathrm{kg} / \mathrm{dm}^{3}\right)\end{array}$ & 2.653 & 2.598 & 2.873 & 2.890 \\
$\begin{array}{c}\text { Characteristic length } \\
(\mathrm{mm})\end{array}$ & 0.60 & 4.75 & 12.50 & 25.00 \\
Fineness modulus & 1.766 & 3.079 & 1.943 & 3.114 \\
\hline
\end{tabular}

\begin{tabular}{cccc}
\hline \multirow{2}{*}{ Characteristic } & \multicolumn{3}{c}{ Chemical admixtures } \\
\cline { 2 - 4 } & Tec-Mult 829 & Tec-Flow 50N & Silicon NS AD 400 \\
\hline Manufacturer & RheoSet & RheoSet & Silicon \\
Appearance / color & Liquid / Dark brown & Liquid / Light brown & Liquid / Dark brown \\
pH & $7.5 \pm 1.0$ & $6.0 \pm 1.0$ & $5.6 \pm 1.0$ \\
Specific weight $\left(\mathrm{g} / \mathrm{cm}^{3}\right)$ & $1.175 \pm 0.02$ & $1.110 \pm 0.02$ & $1.080 \pm 0.02$ \\
\hline
\end{tabular}


Table 3

Concrete materials consumption in $\mathrm{kg} / \mathrm{m}^{3}$

\begin{tabular}{ccc}
\hline Material & \multicolumn{2}{c}{ Consumption $\left(\mathrm{kg} / \mathbf{m}^{3}\right)$} \\
\cline { 2 - 3 } Cement & Conventional concrete (CC) & Concrete with nanosilica (CnS) \\
Silica fume & 390.0 & 390.0 \\
Fine aggregate $0.60 \mathrm{~mm}$ & 30.0 & 30.0 \\
Fine aggregate $4.75 \mathrm{~mm}$ & 220.0 & 505.0 \\
Coarse aggregate $12.5 \mathrm{~mm}$ & 505.0 & 260.0 \\
Coarse aggregate $25.0 \mathrm{~mm}$ & 260.0 & 750.0 \\
Water & 750.0 & 176.0 \\
Chemical admixture - Tec-Mult 829 & 176.0 & 2.83 \\
Chemical admixture - Tec-Flow 50N & 2.83 & - \\
Chemical admixture - Silicon NS AD 400 & 1.10 & 1.10 \\
\hline
\end{tabular}

and superplasticizer polycarboxylates admixtures, one of them being industrially incorporated with colloidal suspension nanosilica (Silicon NS AD 400) and the other without nS (Tec-Flow 50N). The data obtained on the characterization procedures of the aggregates and the specifications of the chemical admixtures supplied by its on manufacturers are presented in Table 2 .

The materials proportion of the concretes was provided by one the most important industries of concrete in the Goiânia District (Brazil) being one of the most commercialized by the company. The concept of using the best-selling mixture proportion of a company is based on the idea of studying close-to-market mixture making the research more applicable to those concrete industries. The proportions of the materials used in the production of the analyzed concretes (CC and $\mathrm{CnS}$ ) are presented in Table 3. These proportions are specific for obtaining compressive strength of $50 \mathrm{MPa}$ and initial slump of $200 \pm 30 \mathrm{~mm}$, according to the data provided by the concrete company.

\subsection{Experimental program}

Two different mixtures were produced with same material and identical proportions, however with different superplasticizer admixtures. The mixture without $\mathrm{nS}$ (CC) was used as study reference to observe the effects of nanosilica in the workability and mechanical strength of concretes; while the other mixture was produced with colloidal suspension $\mathrm{nS}(\mathrm{CnS})$ industrially incorporated to the chemical admixture. To evaluate these properties were carried out slump loss tests as function of time and compressive strength tests at 28 days.

Nine mixtures were studied for each concrete in order to obtain precision in the results. With the view to compare the two mixtures they were produced in different days but in the same hour period (between 12:00 and 17:00). The ambient temperature respected the period of $31 \pm 2^{\circ} \mathrm{C}$ and the relative air humidity $39 \pm 4 \%$ during the whole process of slump determinations according to the ABNT NBR 10342:2012 requests which limits those variations to $2^{\circ} \mathrm{C}$ and $5 \%$ for temperature and air humidity, respectively.

The slump loss through time tests were carried out in accordance with ABNT NBR 10342:2012, which besides the limits to ambient temperature and relative air humidity, presents the necessary equipment and requirements to run the test. According to the prescriptions the test must be considered finished when the mixture achieves slump of $20 \pm 10 \mathrm{~mm}$ or when it is needed according to the researchers. In the study, the tests were terminated when the mixtures reached the consistency class $\mathrm{S} 10$ (slump lower than 50 $\mathrm{mm}$ ) - respecting the NBR 7212 [14] requirements - in order to avoid problems in the specimens casting procedures.

The ABNT NBR NM 67:1998 was the standard basis for determination of slump with intervals of fifteen minutes. The casting and curing of the specimens were performed according to ABNT NBR 5738:2015 and submitted to compressive strength tests at 28 days according to the procedure of ABNT NBR 5739:2007.

\section{Results and discussions}

In this study, the term "workability time" refers to the period from the first slump determination to its closure $(50 \pm 10 \mathrm{~mm})$. Figure 3 shows the average workability times of conventional concrete (CC) and concrete incorporated with nanosilica $(\mathrm{CnS})$ mixtures.

It can be noted that the mixture with colloidal suspension nanosilica, industrially incorporated to the superplasticizer admixture, presented lower workability time than the conventional concrete. The CnS presented a fifteen minutes lower workability time and

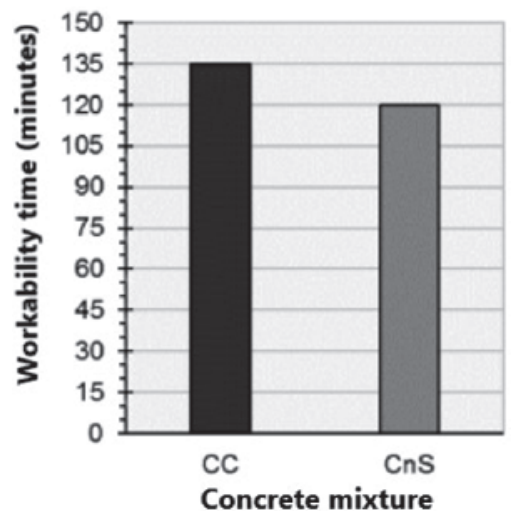

Figure 3

Workability time of the mixtures 


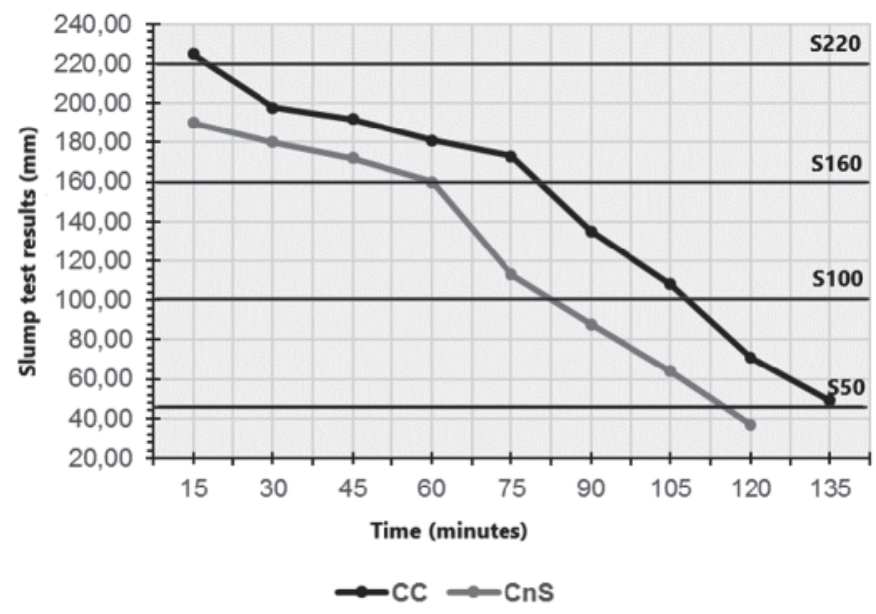

Figure 4

Slump loss evolution of the mixtures

this difference may be a reflection of the initial slumps showed in Figure 4. El-Baky, Yehia and Khalil [9] found that a large part of the water content is used to activate the nS particles due its high specific surface, reducing the initial flowability of the mixture (Figure 4). The nanosilica content of the admixture was not reported by the manufacturer, however basing on El-Baky, Yehia and Khalil [9] results, it can be observed that the content may be lower than $10 \%$ contributing to the mixture slump reduction.

The workability time may influence in the total time that concrete industries have available to produce, transport and cast their mixtures, i.e. perform all the phases properly and respecting the structural project requirements. Any problem in the procedure could make adjustments necessary such as alter the water/cement ratio or exceed the chemical admixtures content limits. The use of chemical admixtures incorporated with nanosilica in concrete mixtures that have to be transported over long distances may not be indicated because it is able to reduce its workability. It will require adjustments to facilitate its casting and it may compromise the hardened concrete properties.

Figure 4 also shows the limiting lines of the concrete consistency

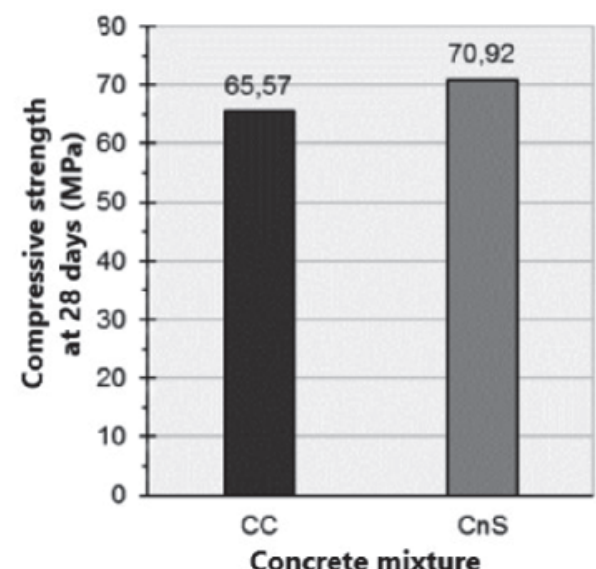

Figure 5

Compressive strength at 28 days classes according to NBR 7212 [14]. Because of the lower initial slump, $190 \mathrm{~mm}$, the CnS mixture was initially in S160 class whereas the CC mixture was fitted to $\mathrm{S} 220$ class, reaching to $225 \mathrm{~mm}$. It is possible to note that the class difference persisted until the last slump determination, where the CnS was in S10 class while the CC was still within the S50 class.

Regarding the slump evolution both concrete mixtures presented similar behavior. It is noted that both mixtures presented linear and descending behaviors. The concrete with addition of nanosilica presented lower slump values in all determinations. It could be possibly explained by the higher water demand resulting from the presence of nS. The CnS started losing workability more quickly after 60 minutes while the $C C$ started after 75 minutes, i.e. once again the fifteen-minute difference remained as a standard. Even though the sudden slump drop occurred at different moments the behavior of both mixtures before and after this moment were similar, proving that the nanosilica only influences the workability by demanding water for its activation. This fact could be corrected by elevating the water content of the mixture without compromising the limits established in norms and in accordance to the environmental aggressiveness classes in which the concrete structure will be built.

To evaluate the mechanical strength, four specimens were prepared for each concrete mixture. The results are presented in Figure 5 where it is possible to note that the concrete incorporated with $\mathrm{nS}$ reached higher compressive strength values at 28 days. This result can be attributed to the pozzolanic effect of the nanosilica studied and presented by Said et al. [3] which, due its high specific surface contributes to the formation of hydrated calcium silicates by means of the pozzolanic reactions between $\mathrm{nS}$ and hydration products, such as calcium hydroxide.

According to the compressive strength values both mixtures are categorized as high strength concretes because they are in the Group II of strength class of ABNT NBR 8953:2015. However, the CnS mixture, which reached $70.92 \mathrm{MPa}$, can be classified as C70 class; while the CC mixture, which reached $65.57 \mathrm{MPa}$, falls within the $\mathrm{C} 60$ class.

Due the nS high specific surface the CnS mechanical strength could have been ever higher but it was approximately 5.0 MPa higher than the CC result. The lack of water content in the $\mathrm{CnS}$ mixture possibly may have contributed to the non-activation of the nS particles reducing the pozzolanic potential of the mineral admixture to the amount of water available for the chemical reactions. In the future, research on the changes in water/cement ratio can be made in order to attest the pozzolanicity of the nanosilica. Moreover, permeability analyzes can also be carried out in order to contribute to the concrete durability studies.

\section{Conclusions}

Based on the results previously showed, the effect of the chemical admixture incorporated with nanosilica on the slump loss and mechanical strength of concretes can be noted. The fresh concrete incorporated with nS presented lower slump values when compared to concrete without nanosilica. This disturbance can reduce the preparation, transportation and casting times of the mixtures and it is necessary to evaluate the possibility of changing the water/cement ratio or to use another chemical admixture, e.g. retarders admixtures. 
In the process of slump loss both mixtures presented similar behavior, i.e. the presence of colloidal suspension nanosilica did not result in excessive slump losses over time. As regards mechanical strength, the presence of $n S$ increased the concrete load capacity expanding the possible applications of the mixture.

In the nanosilica incorporated chemical admixture the content of nS present in its composition is not reported, however when comparing this research results with previous studies, it is believed that the nS content is lower than $10 \%$ because the mixture workability was impaired. Thus, it is the manufacturers responsibility to specify the $\mathrm{nS}$ amount in the solution or to carefully describe the benefits of using the chemical admixture as occurs with the product used in this research.

Lastly, based on the results previously showed, the effect of the chemical admixture incorporated with nanosilica on the slump loss and mechanical strength of concretes can be noted. The fresh concrete incorporated with $\mathrm{nS}$ presented lower slump values when compared to concrete without nanosilica. This disturbance can reduce the preparation, transportation and casting times of the mixtures and it is necessary to evaluate the possibility of changing the water/cement ratio or to use another chemical admixture, e.g. retarders admixtures.

\section{Acknowledgements}

To the Coordenação de Aperfeiçoamento Pessoal de Nível Superior (CAPES) for the financial support. To the companies Realmix Concretos and Impercia - Impermeabilizantes e Especialidades Químicas para Construção for the materials supply. To Universidade Federal de Goiás and its professionals who encouraged and made the accomplishment of this work possible.

\section{References}

[1] SOROKA, I.; RAVINA, D. Hot Weather Concreting with Admixtures. Cement and Concrete Composites, n. 20, p. 129136, 1998.

[2] KOSMATKA, S. H.; KERKHOFF, B.; PANARESE, W. C. Design and Control of Concrete Mixtures. 14. ed. Skokie: Portland Cement Association, 2003.

[3] SAID, A. M.; ZEIDAN, M. S.; BASSUONI, M. T.; TIAN, Y. Properties of concrete incorporating nano-silica. Construction and Building Materials, n. 36, p. 838-844, 2012.

[4] QUERCIA, G.; SPIESZ, P.; HÜSKEN, G.; BROUWERS, J. Effects of amorphous nano-silica additions on mechanical and durability performance of SCC mixtures. In: INTERNATIONAL CONGRESS ON DURABILITY OF CONCRETE, 2012, Norway. Anais... Norway: ICDC, 2012.

[5] QUERCIA, G.; BROUWERS, H. J. H. Application of nano-silica (nS) in concrete mixtures. In: International PhD Symposium in Civil Engineering. 8., 2010, Kongens Lyngby. Anais eletrônicos... Kongens Lyngby: [s.n.]. 2010. Disponível em: <http://www.google.com.br/url?sa=t\&rct=j\&q=\&esrc=s\&so urce=web\&cd=1\&ved=0CCIQFjAA\&url=http $\% 3 \mathrm{~A} \% 2 \mathrm{~F} \% 2 \mathrm{~F}$ www.researchgate.net\%2Fpublication\%2F228442569_Application_of_nano-silica_\%2528nS\%2529_in_concrete_mi xtures\%2Flinks\%2F0c96052430c5abf699000000\&ei=nJuO
VOTTNI_AgwTLkILAAQ\&usg=AFQjCNGPrgaZMBEKIXeR u6pBjIMQcDUInA\&bvm=bv.81828268,d.eXY>. Acesso em: 22 abr. 2016.

[6] GLEIZE, P. J. P. Nanociência e Nanotecnologia dos Materiais Cimentícios. In: ISAIA, G. C. (Ed.) Concreto: Ciência e Tecnologia. 1. ed. São Paulo: IBRACON, n. 2, p. 1871-1884, 2011.

[7] KIM, J. J.; RAHMAN, M. K.; AL-MAJED, A. A.; AL-ZAHRANI, M. M.; TAHA, M. M. R. Nanosilica effects on composition and silicate polymerization in hardened cement paste cured under high temperature and pressure. Cement and Concrete Research, n. 43, p. 78-85, 2013.

[8] BASTAMI, M.; BAGHBADRANI, M.; ASLANI, F. Performance of nano-Silica modified high strenght concrete at elevated temperatures. Cement and Building Materials, n. 68, p. 402408, 2014.

[9] EL-KABY, S. ABD.; YEHIA, S.; KHALIL, I. S. Influence of nano-silica addition on properties of fresh and hardened cement mortar. In: INTERNATIONAL CONFERENCE ON NANOMATERIALS - RESEARCH AND APPLICATION, 5., 2013, Brno. Anais eletrônicos... Brno: Tanger, 2013. Disponível em: <http://www.google.com.br/url?sa=t\&rct=j\&q=\&esrc=s\&sour ce=web\&cd=10\&ved=0CGwQFjAJ\&url=http $\% 3 A \% 2 F \% 2 F w$ ww.researchgate.net\%2Fpublictopics.PublicPostFileLoader. html\%3Fid\%3D52e3b135d4c1186f678b460e\%26key\%3D60 b7d52e3b135e9bb4\&ei=SeEGVcesBsOXgwS5wYGgCA\&us $\mathrm{g}=$ AFQjCNG7ixVID2NqQ3Yfu2FLoX9Sem_sCg\&sig2=4gAlu jZ0e4fBju1MpFHqwQ>. Acesso em: 16 abr. 2016.

[10] MEHTA, P. K.; MONTEIRO, P. J. M. Concreto: estrutura, propriedades e materiais. 2. ed. São Paulo: Pini, 2014

[11] MINDESS, S.; YOUNG, J. F. Concrete. New Jersey: Prentice-Hall Inc., 1981.

[12] AMERICAN SOCIETY FOR TESTING AND MATERIALS. Designation C 494: Standart Specification for Chemical Admixtures for Concrete. West Conshohocken, Pensilvânia, 2013.

[13] TUTIKIAN, B. F.; DAL MOLIN, D. C. Concreto Auto-Adensável. São Paulo: Pini, 2008.

[14] ASSOCIAÇÃO BRASILEIRA DE NORMAS TÉCNICAS. NBR 7212: Execução de concreto dosado em central. Rio de Janeiro, 2012. 